\title{
What is Media Assistance and (Why) Does It Matter? The Case of Polish Foreign Aid to the Media in Belarus and Ukraine
}

\author{
Aleksandra Galus \\ (iD) ORCID: 0000-0002-7081-4187 \\ ADAM MICKIEWICZ UNIVERSITY, POZNAŃ, POLAND
}

\begin{abstract}
The paper offers an analysis of media assistance, as a specific form of foreign aid, that Poland offers to strengthen media development in Belarus and Ukraine. It shows if Poland tailors media assistance according to the local context and existing challenges for democratic changes of recipient countries' media systems. The study builds on the literature concerning the media, development and democratization, in particular looking at media assistance as both democratic aid and public diplomacy. It reveals that Poland's approaches to media development in Belarus and Ukraine do differ: Poland mainly provides autocratic Belarus with technical support for media established outside of that country, while clearly focusing on media capacity development in democratizing Ukraine. The findings show that Polish media assistance, however, is unlikely to boost media freedom in Belarus as is usually expected as an outcome of democratic aid and is under-financed in the case of Ukraine.
\end{abstract}

KEYWORDS: Belarus, foreign aid, media assistance, media development, Poland, Ukraine.

\section{INTRODUCTION}

New democracies are vulnerable to media capture by both political and corporate elites due to fragile institutions, polarized civil society and other deficiencies in their democratic structures, as well as transnational economic pressures that make it challenging for the media to fulfill their functions (Zielonka, 2015). In authoritarian countries, the socio-economic environment ensures media have little or no chance fulfilling their functions. Perceiving democratization and the media as tightly linked, donors of foreign aid engage in delivering support for media development in recipient countries to strengthen democracy (Price, 
2002)1. Such democratic aid idealistically is expected to contribute to democratizing media systems (Higgins, 2014), though in practice, achieving such ambitious goals is not easy due to the high diversity of media systems (Hallin \& Mancini, 2004).

Foreign aid for media development interferes with media systems in recipient countries making this intersection worth studying. This paper aims to analyze Polish media assistance in authoritarian Belarus and democratizing Ukraine by verifying whether Poland's media assistance is differentiated depending on the political contexts and deficits in media freedom in Belarus and Ukraine. Media assistance is examined here, because regional studies regarding external influences on media systems in post-Soviet space, with a few exceptions, are almost nonexistent. This article intends to fill this gap by deepening the understanding of media assistance as a form of democratic aid and public diplomacy at the same time. It adds to the topic's literature findings on specific types of media assistance, their beneficiaries, length and the scope of media assistance projects.

The main reason behind choosing this case study are the different positions of Poland, Belarus and Ukraine in the global system of foreign aid in which Poland functions as a donor country, with Belarus and Ukraine as recipients. After 1989, Poland slowly consolidated democratic order and secured political and civil liberties, while Belarus and Ukraine faced vast problems in the democratization process. Ukraine followed a difficult path of democratization and integration with the EU, experiencing various obstacles in the process of reform, such as the Orange Revolution in 2004, Euromaidan Revolution of 2014, and the subsequent annexation of Crimea in late 2014 and the armed conflict with Russia in Eastern Ukraine. Despite the onset of democracy in Belarus after the dissolution of the Soviet Union, Belarus turned into consolidated authoritarianism under President Lukashenko. Current media systems and the degree of media freedom reflect these developments in Poland, Belarus and Ukraine.

The paper begins with the theoretical framework introducing various approaches related to the links between democratization and media development, grounded in media studies and political science. Next, the article clarifies the case selection and research design, which is followed by the presentation of empirical findings. The results are divided into the general insights into Polish media assistance and detailed elaborations on the characteristics of Poland's support for the development of Belarusian and Ukrainian media. The paper closes with the discussion and recommendations for future research.

1 Foreign aid is understood as Official Development Assistance (ODA). 


\section{MEDIA, DEMOCRATIZATION, AND DEVELOPMENT}

Scholarly consensus views the media as one of the most important components of democracy, as grounded in Dahl's (1989) wide-spread notion of democracy and related concepts. Most of the normative theories of mass media - those describing the ideal roles of media in democracy - point out that the media serve as watchdog, provide sufficient and accurate information and represent citizens. A large body of literature focuses on how the media contribute to society by fulfilling key functions such as information, mobilization and support for deliberate processes in the public sphere (Curran, 2011; McQuail, 2010) with many authors introducing critical angles to the role of the media in democracy. The media have been studied as a subject of reforms (Rozumilowicz, 2002) and as one of the potential factors in the democratization process (Schmitt-Beck \& Voltmer, 2007).

As discussed later, the current shape of media systems in Central and Eastern European (CEE) countries have been found to be linked with the outcomes of system transformation, including transitions to democracy, and marked by various deficits in media freedom (Bajomi-Lázár, 2015; Dobek-Ostrowska, 2012; Jakubowicz, 2005; Štětka, 2012). Media freedom conventionally is perceived as an absence of state interference with media activities; however the economy and other factors have significant impact on them. Research does suggest political regimes influence media freedom and democracy leads to higher levels of media freedom than autocracy (Jakubowicz, 2012; Stier, 2015). Research has not clearly resolved whether media causes political and social change or vice versa (Jebril, Štětka, \& Loveless, 2013). In all likelihood, the media determine neither the success nor failure of system change while the transformation into something more democratic involves multiple challenges because of the existence of interdependencies between the media and the political, economic and social environment (Voltmer, 2013).

Hallin and Mancini (2004) captured the complexities of the media systems by incorporating into their seminal study four dimensions of analysis: political parallelism, the development of media markets, journalistic professionalism and the role of the state. Their claims that media systems are neither homogenous nor static has been confirmed later in CEE countries (Pereira, 2015). Thus, placing the media in the broader context of development and democratization is not an easy task due to the multiplicity of conditions for media changes and their complex relationships with politics, economy and society. The aspect that brings the media and development studies together is that communication and the media have been discussed also as potentially advancing modernization. The core idea of modernization that economic and technological development, along with the media, results in a set of political and social changes, such as democratic 
turns, has been debated for decades with scholars finding modernization being from linearity or universality (Inglehart \& Welzel, 2005).

This acknowledgement was also reflected in the broad criticism of popular paradigms - modernization, imperialism and globalization - in media development studies (Servaes, 2008). Indeed, the discussion moved far beyond the perception of the media solely as an instrument that is rooted in modernization theory and economic development; it became reflected in the term "communication for development" emphasizing the content, which media produce and spread about development (Manyozo, 2012). The relationships between global issues of power and domination and local complexities inspired scholars to put more emphasis on a participatory approach towards the media and its updated versions highlighting the use of the media in the process of bottom-up change, which delegates power to local communities (Servaes, 2008; Sparks, 2007). This approach is valuable from the perspective of the concept of "human empowerment" in democratization theory, which assumes empowered citizens are capable, willing and entitled to practice freedoms (Welzel, 2009). Research representing a strong orientation towards participation was anchored in the idea of Putnam's social capital and networks, though the theory commonly views media only as a mediator in development (Putnam 1995 cited by Manyozo, 2012).

However, the assumptions on media roles in the context of democratization previously presented have been an impulse to explore "media development" understood as a change in the field of communications. It relates to "a range of institutions, practices, and behaviors including the rule of law, freedom of expression, education systems for journalists, business environments, capacities of journalists and managers, as well as support for a diversity of views in society" (Myers \& Juma, 2018, p. 3). On the levels of theory, policy and practice media development entails external and organic, organized efforts to develop the capacity of media policies, structures and ownership as a pathway to support democratization and good governance (Manyozo, 2012) exceeding an instrumental use of media in "communication for development". Due to mostly being based on political economy and democratic theory, with some underpinnings from works on social change and community media, the media development approach fits the discussion on the media in transitional democracies. Nonetheless, it is not free from challenges related to criticism of liberal democracy that - as a theoretical concept - usually serves as a benchmark for donors providing media assistance. 


\section{MEDIA ASSISTANCE AS FOREIGN AID}

Media development is a process occurring at various levels that started to be supported externally when the understanding of the media among the international aid community shifted from an instrument to achieve development goals to being seen as a subject of democratic change per se. A vivid example of such an approach that focuses on media roles in transitional democracies could be United States Agency for International Development (USAID) that builds its assistance for the media on the Anglo-Saxon tradition of access to information (Carpentier \& Cammaerts, 2007). Media assistance media development perspective present also in the support from other donors' - countries, international organizations, NGOs - as premised on the concepts of freedom of speech, media pluralism and independence from the state and market (Manyozo, 2012).

As follows, media assistance can be defined simply as financing media development by donors (Myers \& Juma, 2018). When analyzing media assistance, alternatively named in the literature as "international media assistance" or "media interventions" (Irion \& Jusić, 2014), most scholars agree that it relies on promoting the free flow of information, capacity building and journalism trainings, institutional support and other activities aimed at strengthening media where freedom is limited (Howard, 2003; Kumar, 2009; Price, 2002; Rhodes, 2007). According to existing research, donors usually expect media assistance programs to help to "produce better journalism, better media organizations and better media systems" (Higgins, 2014, p. 2). The far-reaching goal of media assistance is to foster democratic development, which has been considered as a political type of intervention (Rotham, 2015), as in the case of American aid for media development.

Extant research reveals that the motives of engagement in foreign aid vary from country to country and include the promotion of donors' political, economic and strategic interests, regional, cultural and historical ties, including post-colonial heritage, humanitarian reasons and solidarity (Kopiński, 2011). Media assistance is no exception here. The romanticized vision of the media in democracy, Western-centrism and its politicized character resulted in criticism of media assistance (Higgins, 2014; Miller, 2009). Such efforts pose the question of power and the influence of donors' agendas and media systems on what media development initiatives are funded with what objectives, and engaging which stakeholders (Manyozo, 2012). Thus, ideological foundations of media freedom may lead to mirroring Western solutions through foreign aid. Media assistance, like other forms of democratic aid, can be considered from the perspective of the diffusion of democratic norms and values (Gleditsch \& Ward, 2006) and from the perspective of domination because both the media and foreign aid comply with the idea of soft power (Nye, 2004; Warren, 2014). The soft power-media 
nexus is clearly visible in the Russian-Ukrainian struggle over information space, in which news media play a critical role in shaping dominant narratives (Szostek, 2014) ${ }^{2}$.

The latter two contexts bring to the debate on external support for media development the issue of (new) public diplomacy understood as a dialogical form of international political communication that by building mutually beneficial relations with partners abroad facilitates the achievement of state's goals in the international area (Ociepka, 2017). One of components of public diplomacy is international broadcasting aimed at engaging a foreign public (Cull, 2019). Donors' support for their own international broadcasters, such as expenses for Deutsche Welle or Belsat reported to OECD as foreign aid in case of Germany and Poland respectively, shows that some efforts within media assistance advance public diplomacy too (Myers \& Juma, 2018; Ociepka, 2016). Looking wider, such support entails the element of ideological and geopolitical struggle as discussed by Schiller (1976) in terms of cultural domination in media development. Hence, it has been argued that the biggest democratization potential lies in programs that favor media freedom inside recipient countries rather than in investments in technical media infrastructure, communication for development or international broadcasting (Cauhapé-Cazaux \& Kalathil, 2015). Supporting domestic media and human resources in developing countries through foreign aid corrresponds with global recommendations to ensure local ownership of aid projects.

Another challenge related to media assistance is its alignment to deficits in media freedom in target countries. As explained earlier, media systems across the world are not homogenous which makes external support for media highly context dependent. Kumar (2009) suggests that "one size does not fit all", and thus support for media development needs to be tailored to local needs and differentiated accordingly to whether a recipient is an authoritarian state, democratizing country, war-torn or post-conflict society. In other words, due to the political nature of media assistance, donors should acknowledge the political environment of where they send aid. Works on other sectors of democracy assistance confirm the necessity to design programs accordingly to the wider socio-political context in recipient countries and, if possible, engage local partners and civil society that can bypass governments (Pospieszna, 2019) and thus avoid the "taming" of aid (Bush, 2015). Introducing civil society into support for media development and the focus on capacity building (Cauhapé-Cazaux \& Kalathil, 2015) bring this form of aid closer to the participatory paradigm in development studies.

2 In this conflict Russian international broadcaster RT is usually perceived as advancing Russia's soft power. 
Discussing challenges in media assistance and empirical evidences from post-Soviet region, existing studies concentrated first and foremost on support dedicated to the Balkans (Irion \& Jusić, 2014; Rhodes, 2007) where donors tested foreign aid in various ways, achieving mixed results in the contributions of media interventions to democratization of media systems. Western support for media development in Ukraine was found to be generous and successful in establishing media freedom watchdog, and monitoring, NGOs (Tsetsura, Grynko, \& Klyueva, 2011). Among new donors from CEE, Poland appeared to be active in supporting media mainly in Eastern Partnership countries by engaging civil society, sharing transition experiences and strengthening media independence, however, without a strategic approach and long-term vision (Zalas-Kamińska, 2019). Although Polish activities in this regard are reported as democratic aid, scholars discussed them also as motivated by ensuring regional stability (Kaca, 2011) and pursuing the objectives of public diplomacy to strengthen the position of Poland in international communication, especially through the foundation of Belsat as international TV for Belarus (Ociepka, 2017; Zalas-Kamińska, 2019). Thus, one of the biggest challenges of external support for media development could be seen as alignment to existing needs in recipient countries above the interests of donors.

\section{THE STUDY}

\section{CASE SELECTION: POLAND AS A DONOR, BELARUS AND UKRAINE AS RECIPIENTS}

While several studies have demonstrated the characteristics of democratic aid provided by traditional donors, such as the USA and the EU members in Western Europe, less attention has been devoted to younger democracies in CEE that also may influence recipient countries through foreign aid. Media assistance interferes with media systems in countries that receive external support and thus the discrepancies in democratic development of political regime and media between Poland seen as a "new" donor and Belarus and Ukraine seen as recipients of foreign aid matter. Poland joined the EU in 2004 and consolidated its electoral democracy, but has recently experienced a significant democratic decline (Lührmann \& Lindberg, 2019). During the 1990s and early 2000s Ukraine developed its competitive authoritarianism (Levitsky \& Way, 2010) and even in post-Maidan reality has been usually assessed by scholars as a hybrid regime (Matsiyevsky, 2018). Belarus at the same time has remained a stagnant, electoral autocracy (Lührmann \& Lindberg, 2019). 
Along with the political evolution in post-communist region, democratization also brought changes in media systems. Based on Hallin and Mancini's (2004) typology of media systems, other scholars potrayed CEE media systems, including the Polish one, as undergoing the process of "Italianization" or "Mediterraneanization" (Dobek-Ostrowska, 2012) characterized by politicization, state control over media and party colonization among other features (Bajomi-Lázár, 2015). Thus, media systems in this part of Europe can be perceived as similar to the "Polarized Pluralist" model with influences of both "Liberal" and "Democratic Corporatist" models (Hallin \& Mancini, 2013). Extending this framework, Dobek-Ostrowska (2015) classified the Polish model of the media and politics as "Liberal Hybrid" marked by commercialization, hybridization and the freedom, the Ukrainian model as "Media in Transition" with delayed modernization and strong political pressure, and the Belarusian model as "Authoritarian" with a restrictive political environment and the lack of freedom.

Moreover, media freedom as a non-electoral component of democracy can be easily in decline (Lührmann \& Lindberg, 2019), which slowly is happening in Poland. Nonetheless, it is the situation of recipient countries that is crucial in providing foreign aid to the media. Existing case studies have managed to capture the developments and deficits of such media systems. Although Ukraine experienced improvements in media freedom since the dissolution of the Soviet Union, the Ukrainian media system struggles with politicized ownership and pluralism limited to oligarchs' interests, ownership centralization is conditioned by both economic and political reasons, wide-spread informal pratices and commercialization (Dyczok, 2015; Ryabinska, 2017). In the case of Belarus, the leading scholarly narrative is that the media are highly controlled and repressed, used for propaganda purposes with strong influences of Russia and the internet serving as a crucial channel of alternative information (Manayeva, Aniskevich, \& Dinerstein, 2011; Sahm, 2009).

Existing scholarship on the media in Belarus and Ukraine can be supplemented with Varieties of Democracy data on media as a component of democracy ${ }^{3}$. Belarusian media suffer the most from government censorship, biased coverage, media corruption, and the lack of criticism. The situation of media in Belarus is rather stable but very unfavorable. Ukrainian media, in turn, struggle with political interference, oligarchic ownership, poor journalistic standards and harassments of journalists in the war zone. The Euromaidan Revolution brought about the decline in media freedom in Ukraine due to legal limitations on the press being imposed by the former president Yanukovych and an increase

3 Varieties of Democracy (V-Dem) is a new academic approach to conceptualizing and measuring democracy. It is based on five main principles of democracy: electoral, liberal, participatory, deliberative, and egalitarian with media freedom perceived as an important attribute of democracy, https://www.v-dem.net (accessed: 28.06.2020). 
in violence against journalists during the protests. Journalists from Ukraine also face the negative consequences of information warfare with Russia, such as disinformation and no-go areas on the separatist-controlled territories. The challenges to increasing media freedom in Belarus and Ukraine, as explained, may suggest potential areas for media assistance provided by donor countries.

\section{RESEARCH OBJECTIVES AND METHODS}

The present study focuses on Polish foreign aid for media development in Belarus and Ukraine in relation to varying political environments, media systems and deficits in media freedom in donor and recipient countries. It draws on the media, democratization and development literature corresponding with pioneering studies conducted by Ociepka (2017) and Zalas-Kamińska (2019) that linked Polish development cooperation with public diplomacy and by Kaca (2011) and Pospieszna (2019) focusing on democratic aid. To deepen the understanding of Poland's media assistance, this study aims to address the question about whether foreign aid coming from Poland, currently struggling with the erosion of non-electoral components of democracy itself, varies according to the local context in Belarus and Ukraine. The article asks several research questions: What is the scope of Polish media assistance in Belarus compared to Ukraine? What are the similarities and differences in Polish aid for development of Belarusian and Ukrainian media? Is media assistance tailored to deficits in media freedom in recipient countries?

The research relied on qualitative document analysis and a comparative method. Firstly, the background of Poland's media assistance in Belarus and Ukraine was studied on the basis of strategic documents and annual reports produced by the MFA RP. Secondly, a database of Polish projects aimed at strengthening Belarusian and Ukrainian media implemented within the framework of foreign aid was compiled in order to compare the amount of funding, length of media interventions, types of undertaken initiatives, and the beneficiaries of media assistance projects. The main sources of data for coding included ministerial records, the reports of NGOs engaged in the realization of media assistance projects as well as available datasets (microdata derived from Creditor Reporting System (CRS) developed by $\mathrm{OECD}^{4}$, a repository of projects published by Polish $\mathrm{Aid}^{5}$ ). The study covers the period of 2008-2018 due to the availability of data that in terms of the upper boundary extends existing studies dealing with Polish media assistance.

4 CRS: https://stats.oecd.org/Index.aspx?DataSetCode=CRS1 (accessed: 18.01.2020).

5 Repository: https://www.polskapomoc.gov.pl/Repository,of,projects, 1945.html (accessed: 18.01.2020). 


\section{EXPLORING POLISH MEDIA ASSISTANCE IN BELARUS AND UKRAINE: AN OVERVIEW}

Poland committed to contributing to global development subsequent to signing international obligations, joining the EU and the Development Assistance Committee of OECD. As a relatively new donor which was a recipient of foreign aid itself during political, social and economic changes in the 1980s and 1990s, Poland made its own system transformation experience a pillar of its development cooperation with partner countries (MFA RP, 2013). In contrast to multilateral aid, bilateral aid is particularly important because a donor country autonomously decides on the direction of given aid, its scope and type. Poland intentionally has chosen Belarus and Ukraine as priority aid recipients as clarified in the Multiannual Development Cooperation Programs (for 2012-2015 and 2016-2020) ${ }^{6}$. Despite the lack of a clearly defined list of main recipients of Polish foreign aid before 2012, since 2004 Poland has provided consistent support to Belarus and Ukraine, including media assistance. The analysis of strategic documents shows that the support for media development has been placed within a wider context of Polish democratic aid, however, high priority has been assigned to media assistance only in case of Belarus. As Zalas-Kamińska (2019) argued, a clear reference to Polish democratic aid as a public diplomacy has been made by politicians, years after the initiation of development initiatives supporting democracy, including the media.

The basis for Poland's commitment to supporting media development was the designation of "democracy and human rights" as preferred areas of foreign aid along with strengthening public access to information and social control over the media (MFA RP, 2012) which also has been discussed by other scholars arguing about the political nature of Polish aid (Ociepka, 2017). Media assistance has been romantically framed as a remedy for democratic deficits, as constituting a development goal itself, or as being an important mean to increase good governance in the case of Belarus. In the context of Ukraine, support for access to reliable and objective information was indicated as one of many possible ways to support democracy through good governance (MFA RP, 2012, 2015). Hence, the answer to the question about why Poland assist media development in Belarus and Ukraine is that it results from the belief in the relevance of independent media and objective information in the process of democratization, which supports previous studies highlighting Western-centric and liberal roots of donors' thinking about media assistance. Moreover, the Polish MFA did not provide systemic and critical analysis of recipient countries' media systems in strategic documents.

6 Polish Aid, https://www.polskapomoc.gov.pl/Multiannual,framework,181.html (accessed: 26.06.2020). 
The most important issue, however, is whether the discussed "need" to provide media assistance by Poland expressed on the level of policy documents translated into actual aid for media development in Belarus and Ukraine. Based on annual reports about Polish development cooperation, the overall Polish media assistance expenditure in Belarus and Ukraine were calculated for the period of 2008-2018 . Figure 1 presents bilateral aid dedicated to media development in Belarus and Ukraine.

Figure 1. Poland's Foreign Aid to Media in Belarus and Ukraine

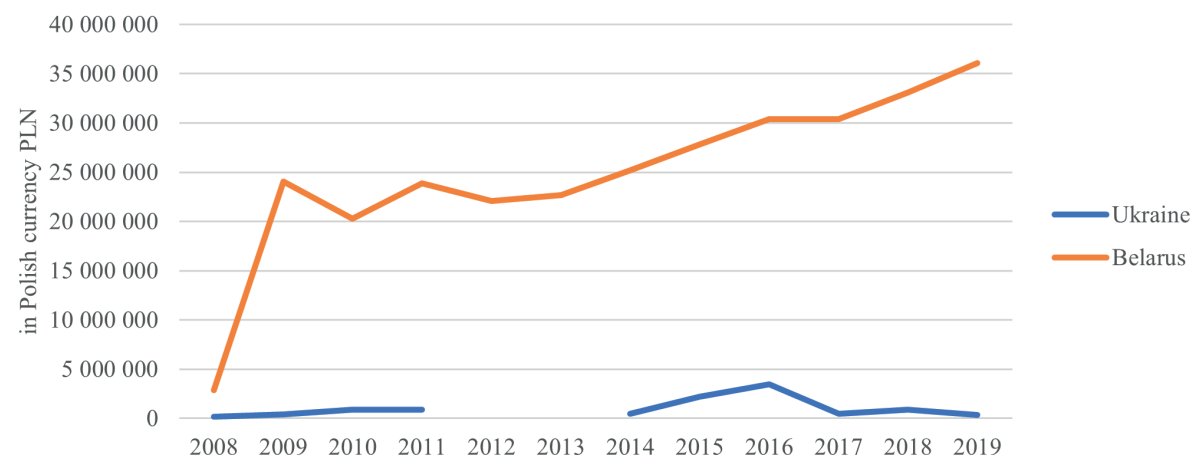

Source: Own calculations based on annual reports (2008-2018) published about Poland's development cooperation are published by the Ministry of Foreign Affairs of the Republic of Poland and publicly available in Polish Aid's knowledge base: https://www. polskapomoc.gov.pl/Publications, 2798.html (accessed: 22.01.2020). The gaps in data on the scope of funding for projects in Ukraine were found for the period of 2011-2013

The collected data clearly indicate that, over the analyzed period, Belarus received much more generous support for media development than Ukraine. Both countries were top beneficiaries of Polish democratic aid overall, but there were significant differences in the amount of Polish expenditure on media assistance. This, in return, might indicate that Poland assigned more importance to media development in Belarus, where the state of media freedom is more critical than in Ukraine, but also where Poland makes various attempts to gain political influence. Higher funding for media assistance in Belarus corresponds with the prioritization of areas of foreign aid defined in Polish program documents. Despite the lack of significant progress in the development of media freedom over time, Polish support continued in Belarus, which supports the claim about Poland's stance on media assistance being grounded in public diplomacy rather than capacity building through foreign aid. In Ukraine, where Poland's media assistance was much more modest, the level of media freedom was much higher

7 The annual reports on Poland's development cooperation are publicly available in Polish Aid's knowledge base: https://www.polskapomoc.gov.pl/Publications,2798.html (accessed: 22.01.2020). 
at the same time. Aid increased at the most critical moment: during and after Euromaidan when journalists experienced harassments and legal constraints, which reflects some kind of reaction by Poland to the current socio-political developments in Ukraine.

However, the statistics do not tell the whole story of Poland's engagement in neighboring countries aimed at boosting media freedom. Specifically, the presented aid flows allow only the claim that Poland favored media development in Belarus and that Ukraine was not left without any support while media freedom has declined. On the other hand, the findings do not explain whether media assistance provided to Belarus and Ukraine matches the existing deficits in media freedom. Knowing that "one does not fit all", it is verified that Poland brings theory into practice and diversifies aid by acknowledging the local conditions. To explore more deeply these findings, the next section investigates Polish media assistance disaggregated into specific types of support, its beneficiaries, length and the scope of the development projects.

\section{BELARUS AND UKRAINE: DIFFERENT NEEDS, DIFFERENT MEDIA ASSISTANCE}

In order to assess whether Polish foreign aid takes into account political regime type and the situation of the media, selecting Poland as a donor, Belarus and Ukraine as aid recipients was justified by the different outcomes of the democratization process, including the state of media freedom. As clarified earlier, the situation of media in Belarus and Ukraine undoubtedly differs mainly due to political developments, so it can be expected that neither will media assistance be homogenous. To answer vital questions regarding contrasts in Polish foreign aid dedicated to the media in Belarus and Ukraine, media projects that were implemented within the last ten years have been gathered in a database and coded on the basis of ministerial documents, OECD microdata and available projects' descriptions.

The analysis of collected data reveals that Poland's media assistance in Belarus and Ukraine was designed differently not only because of the funding, but mostly due to targeting divergent fields of media development. Qualitative examination of projects indicates that media assistance dedicated to Belarus was technical and consisted of substantial financial boosts for media that were established on the territory of Poland as a result of Polish foreign aid. There were three Belarusian "media in exile" that consumed a vast majority of Polish donations to media development in Belarus: Belarusian Radio Racya, Euroradio and TV Belsat. Ociepka (2016) examined the latter in great detail showing how it is a Polish station presenting Polish-centric and anti-Lukashenko narratives and used for gaining leverage by Poland in the communication sphere.

This type of support was aimed at increasing access to alternative sources of online or on-air information available for Belarusians living in the borderlands, 
since there is no space for independent journalism in Belarus; however, in the form of purely technical support, Polish media assistance did not confront directly the authoritarian rule in Belarus. Probably, media assistance did not contribute to preventing the state harassment of Belarusian journalists who work in the country. This type of media assistance should rather be treated rather as a provision of a very basic need, which is the access to information free of censorship. Thus, Poland supported online libraries rather than people. Focusing on establishing and maintaining media outlets based outside an authoritarian country is less likely to improve journalism in autocratic Belarus and interfere with the "closed" Belarusian media system. There was also no place for sharing Polish transition experience with e.g. media reforms in Belarus, as declared in the strategic documents, which constituted a solid part of the projects implemented in Ukraine.

By contrast, the support for Ukrainian media had a much more multi-faceted nature. Although poorly funded, it combined the most coverage of specific issues - largely the conflict with Russia, decentralization reform and the integration with the EU - with technical support and trainings for journalists in traditional journalism and new media. Less common types of media assistance, such as the support for building mechanisms of media accountability, entrepreneurial guidance, legal advice and the right to information campaigns were also present to some extent, usually as complementary support. Media assistance mostly took a public diplomacy stance in Ukraine in some capacity building projects for journalists that focused on countering Russian disinformation and information influences over Ukraine. This might imply that Poland not only supports, but also politically and culturally influences Ukraine, opposing its antagonist Russia. On the other hand, many initiatives targeted context dependent problems of the Ukrainian media system, such as editorial independence or countering corruption. Media projects in Belarus were annually resumed in most cases because of the unchanged recipients, being just one TV and two radio stations, while in Ukraine the support was more fragmented and not always continued. Table 1 shows the features of Polish media assistance.

Table 1. Polish Foreign Aid for Media in Belarus and Ukraine (\% of projects by country)

\begin{tabular}{|c|c|c|}
\hline Type of media assistance & Belarus & Ukraine \\
\hline Material and technical support & 67.21 & 17.35 \\
\hline Legal and policy support & 0.00 & 6.12 \\
\hline Trainings in journalism & 11.48 & 14.29 \\
\hline Coverage of specific issues & 8.20 & 36.73 \\
\hline Advocacy for independent media & 0.00 & 8.16 \\
\hline
\end{tabular}




\begin{tabular}{|c|c|c|}
\hline Type of media assistance & Belarus & Ukraine \\
\hline $\begin{array}{l}\text { Trainings in entrepreneurship } \\
\text { Support for media professional organizations and networking } \\
\text { Media literacy and education }\end{array}$ & $\begin{array}{c}1.64 \\
1.64 \\
9.84 \\
\mathrm{~N}=61\end{array}$ & $\begin{array}{c}7.14 \\
5.10 \\
5.10 \\
\mathrm{~N}=98\end{array}$ \\
\hline \multicolumn{3}{|c|}{ Beneficiaries of media assistance } \\
\hline $\begin{array}{l}\text { Journalists } \\
\text { Media workers (non-journalists) } \\
\text { Media as institutions (news outlets) } \\
\text { Civil society } \\
\text { Political actors } \\
\text { Youth } \\
\text { Educational sector } \\
\text { Local community } \\
\text { Groups with special needs } \\
\text { The society }\end{array}$ & $\begin{array}{c}21.31 \\
0.00 \\
62.30 \\
3.28 \\
0.00 \\
1.64 \\
0.00 \\
0.00 \\
0.00 \\
11.48 \\
\mathrm{~N}=61\end{array}$ & $\begin{array}{c}50.00 \\
8.51 \\
19.15 \\
10.64 \\
5.32 \\
0.00 \\
0.00 \\
2.13 \\
1.06 \\
3.19 \\
\mathrm{~N}=94\end{array}$ \\
\hline \multicolumn{3}{|l|}{ Scope of projects } \\
\hline $\begin{array}{l}\text { Regional } \\
\text { National } \\
\text { International }\end{array}$ & $\begin{array}{c}3.64 \\
96.36 \\
0.00 \\
\mathrm{~N}=55\end{array}$ & $\begin{array}{c}57.14 \\
34.69 \\
8.16 \\
\mathrm{~N}=56\end{array}$ \\
\hline \multicolumn{3}{|l|}{ Length of projects } \\
\hline $\begin{array}{l}\text { One year } \\
\text { Long-term }\end{array}$ & $\begin{array}{c}7.14 \\
92.86 \\
\mathrm{~N}=56\end{array}$ & $\begin{array}{l}50.00 \\
50.00 \\
\mathrm{~N}=50\end{array}$ \\
\hline
\end{tabular}

Source: Based on author's own coding. The type of media assistance and beneficiaries of types of support were coded allowing the use of up to three categories at the same time due to the complexity of projects. Data were not available in case of 1 project in Belarus (concerning the scope) and 6 projects in Ukraine (related to the length)

Another essential finding from this study is that Polish media assistance targeted a variety of audiences. Put another way, the projects did not strengthen the same beneficiaries in authoritarian Belarus and democratizing Ukraine. Capacity building of journalists through foreign aid was much stronger in the case of Ukraine than Belarus. When assistance is given to particular news outlets, journalists also benefit. However, this type of media intervention treated press, radio, television and online media as institutions and concentrated on their sustainability (or survival) rather than empowering journalists as individuals. Those differences were clearly observable in the example of projects addressed to regional journalists or focusing on local issues. Regional support was marginal in Belarus, which might mean leaving some unmet problems with local journalism. It can be concluded that assistance was invested "in people" much more in Ukraine than in Belarus, which - according to the literature review - is a more effective way to foster media development and ensure local ownership.

Last but not least, the engagement of civil society in media projects should be clarified. Unlike in Ukraine, media assistance in Belarus was directed mainly to the three news outlets, without much emphasis on human resources. While 
civil society was almost absent in media assistance in Belarus, it played a double role in Ukraine. Civil society organizations (CSOs) and activists were not only direct beneficiaries in some cases, as described in Table 1, but also important contributors to foreign aid. CSOs took part in media assistance as partners and co-organizers, some of Ukrainian media, which received support and held NGO status. The analysis of descriptions of projects for media in Ukraine showed that the involvement of Ukrainian civil society in the implementation of support was widespread. Thus, active participation of non-state actors in media assistance sheds a positive light on this kind of development cooperation, because previous findings from the literature indicate that local partners have a fair recognition of what is really needed in their countries (see for example, Pospieszna, 2019).

\section{DISCUSSION}

Empirically, this article investigated media assistance given by Poland as a new donor and verified whether Polish foreign aid to the media took various forms in authoritarian Belarus and democratizing Ukraine. First, it showed that the aid actively supported media in Belarus and Ukraine, which is consistent with Polish development cooperation policy. However, the funds were distributed unequally, making Belarus a more privileged beneficiary of media assistance. Secondly, Polish foreign aid to the media was differentiated according to political regime type in recipient countries, taking into consideration the deficits in media freedom. This differentiation was demonstrated by the increases in expenditure during critical moments and variations in the type of offered support for media development. Polish foreign aid for media in Belarus was grounded on building in Polish territory, Belarusian radio stations and television transmitters to satisfy the basic need of access to reliable information, which was identified as efforts within public diplomacy. At the same time, Ukrainian media were supported by projects focused on capacity development and coverage of current but difficult topics, such as the war in Donbas. While in the context of Belarus, Poland targeted mainly the media in exile, being less likely to contribute to the democratization of the Belarusian media system, media assistance in Ukraine was much more diversified and dedicated to a wider range of beneficiaries, resulting in closer links to civil society development and thus, more democratically-oriented in its nature.

The paper endeavors to add to the literature on media development of the linkages between media and foreign aid in the post-communist region. Examining Poland - a country that has recently received extensive criticism due to violations of democratic rule and media freedom at home - brings attention to so-called new donors' engagement in the provision of democratic aid abroad. The 
examinations of Polish media assistance in Belarus and Ukraine revealed that media interventions can contribute to the emergence of new media outlets, new media frameworks and other developments, that do intervene to some extent with media systems. However, a detailed assessment of media assistance effectiveness exceeds the scope of this paper and requires using other research methods. Media assistance is only one of many forces that influence changes in media systems along with other external and internal factors. Comparative and quantitative analysis would be beneficial in deepening the understanding of external interventions and power relations, while a more qualitative approach might bring more answers to questions regarding systemic analysis of media systems in recipient countries and how they are impacted by media assistance, as well as the exact roles of civil society in foreign aid. Thus, this study servers as an initial diagnosis of what media assistance is and why it matters to the example of Polish support for media development in Belarus and Ukraine.

\section{ACKNOWLEDGEMENTS}

This work was supported by National Science Centre (NCN) in Poland [grant number UMO-2017/25/N/HS5/01404]. The author wishes to thank Susan T. Jackson for proofreading and comments.

\section{REFERENCES}

Bajomi-Lázár, P. (2015). Variations in media freedom: Why do some governments in Central and Eastern Europe respect media freedom more than other ones? Central European Journal of Communication, 8(14), 4-20.

Bush, S. S. (2015). The taming of democracy assistance. Why democracy promotion does not confront dictators. Cambridge: Cambridge University Press.

Carpentier, N., \& Cammaerts, B. (Eds.) (2007). Reclaiming the media: Communication rights and democratic media roles. Bristol and Portland: Intellect Books.

Cauhapé-Cazaux, E. G., \& Kalathil, S. (2015). Official development assistance for media: Figures and findings. Washington DC: Center for International Media Assistance.

Cull, N. J. (2019). Public diplomacy. Foundations for global engagement in the digital age. Cambridge: Polity Press.

Curran, J. (2011). Media and democracy. London and New York: Routledge.

Dahl, R. (1989). Democracy and its critics. New Haven: Yale University Press.

Dobek-Ostrowska, B. (2012). Italianization (or Mediterraneanization) of the Polish media system? Reality and perspective. In D. C. Hallin \& P. Mancini (Eds.), Comparing media systems beyond the Western world (pp. 26-50). New York: Cambridge University Press. 
Dobek-Ostrowska, B. (2015). 25 years after communism: four models of media and politics in Central and Eastern Europe. In B. Dobek-Ostrowska \& M. Głowacki (Eds.), Democracy and media in Central and Eastern Europe 25 Years On (pp. 11-45). Bern: Peter Lang.

Dyczok, M. (2015). Threats to free speech in Ukraine: The bigger picture. In G. E. Brogi, M. Dyczok, O. Pachlovska, \& G. Siedina (Eds.), Ukraine twenty years after independence. Assessments, perspectives, challenges (pp. 141-155). Rome: ARACNE editrice.

Gleditsch, K. S., \& Ward, M. D. (2006). Diffusion and the international context of democratization. International Organization, 60(4), 911-933.

Hallin, D. C., \& Mancini, P. (2004). Comparing media systems: Three models of media and politics. Cambridge: Cambridge University Press.

Hallin, D. C., \& Mancini, P. (2013). “Comparing Media Systems” between Eastern and Western Europe. In P. Gross \& K. Jakubowicz (Eds.), Media transformations in the post-communist world: Eastern Europe's tortured path to change (pp. 15-32). Lanham: Lexington Books.

Higgins, D. (2014). The Western way? Democracy and the media assistance model. Global Media Journal, 4(2), 1-15.

Howard, R. (2003). International media assistance: A review of donor activities and lessons learned (No. Working Paper 19). Hague: Netherlands Institute of International Relations "Clingendael" Conflict Research Unit (CRU).

Inglehart, R. F., \& Welzel, C. (2005). Modernization, cultural change, and democracy: The human development sequence. Cambridge: Cambridge University Press.

Irion, K., \& Jusić, T. (2014). International assistance and media democratization in the Western Balkans: A cross-national comparison. Global Media Journal-German Edition, 4(2), 1-29.

Jakubowicz, K. (2005). Post-communist media development in perspective. Friedrich-Ebert-Stiftung.

Jakubowicz, K. (2012). Post-communist political systems and media freedom and independence. In J. Downey \& S. Mihelj (Eds.), Central and Eastern European media in comparative perspective. politics, economy and culture (pp. 15-40). Farnham: ASHGATE.

Jebril, N., Štětka, V., \& Loveless, M. (2013). Media and democratisation: What is known about the role of mass media in transitions to democracy. University of Oxford.

Kaca, E. (2011). Pomoc demokratyzacyjna w polskiej wspótpracy rozwojowej. Warsaw: Ośrodek Studiów Wschodnich.

Kopiński, D. (2011). Pomoc rozwojowa. Teoria i praktyka. Warszawa: Difin SA.

Kumar, K. (2009). One size does not fit all. Objectives and priority areas for media assistance in different societies. Washington: Center for International Media Assistance.

Levitsky, S., \& Way, L. (2010). Competitive authoritarianism: Hybrid regimes after the Cold War. Cambridge: Cambridge University Press.

Lührmann, A., \& Lindberg, S. I. (2019). Democracy facing global challenges. V-Dem annual democracy report 2019. (A. Lührmann \& S. I. Lindberg, Eds.). Gothenburg: University of Gothenburg.

Manayeva, N., Aniskevich, A., \& Dinerstein, A. (2011). Mass media under the eye of Big Brother: Governmental control over mass media in Belarus. Otázky Žurnalistiky, 54(3-4), 3-19.

Manyozo, L. (2012). Media, communication and development. Three approaches. New Delhi: SAGE Publications. 
Matsiyevsky, Y. (2018). Revolution without regime change: The evidence from the post-Euromaidan Ukraine. Communist and Post-Communist Studies, 51(4), 349-359.

McQuail, D. (2010). McQuail's mass communication theory. London: SAGE Publications.

Miller, J. (2009). NGOs and 'modernization' and 'democratization' of media: Situating media assistance. Global Media and Communication, 5(1), 9-33.

MFA RP. (2013). Polskie doświadczenia transformacyjne w programie Polskiej Pomocy. Warsaw: Departament Współpracy Rozwojowej Ministerstwa Spraw Zagranicznych RP.

MFA RP. (2012). Wieloletni program wspótpracy rozwojowej na lata 2012 - 2015. Solidarność, demokracja, rozwój. Warsaw: Ministerstwo Spraw Zagranicznych RP.

MFA RP. (2015). Wieloletni program współpracy rozwojowej na lata 2016-2020. Warsaw.

Myers, M., \& Juma, L. A. (2018). Defending independent media: A Comprehensive analysis of aid flows. Washington DC: Center for International Media Assistance.

Nye, J. S. (2004). Soft power: The means to success in world politics. New York: PublicAffairs.

Ociepka, B. (2017). Poland's new ways of public diplomacy. Frankfurt am Mein: Peter Lang.

Ociepka, B. (2016). International broadcasting by a middle-size country: The case of Belsat TV from Poland to Belarus. Global Media and Communication, 12(2), 111-126.

Pereira, J. S. (2015). Variety of media systems in third-wave democracies. In J. Zielonka (Ed.), Media and politics in new democracies. Europe in a comparative perspective (pp. 231-247). Oxford: Oxford University Press.

Pospieszna, P. (2019). Democracy assistance bypassing governments in recipient countries. Supporting the "next generation." Abingdon and New York: Routledge.

Price, M. (2002). Mapping media assistance. The Programme in Comparative Media Law \& Policy, Centre for Socio-Legal Studies, University of Oxford.

Putnam, R. D. (1995). Bowling alone: America’s declining social capital. Journal of Democracy, 6(1), 65-78.

Rhodes, A. (2007). Ten years of media support to the Balkans: An assessment. Amsterdam: Media Task Force of the Stability Pact for South Eastern Europe.

Rotham, P. (2015). The politics of media development. The importance of engaging government and civil society. Washington: Center for International Media Assistance.

Rozumilowicz, B. (2002). Democratic change. A theoretical perspective. In M. E. Price, B. Rozumilowicz, \& S. G. Verhulst (Eds.), Media reform: Democratizing the media, democratizing the state. Abingdon: Routledge.

Ryabinska, N. (2017). Ukraine's post-communist mass media. Between capture and commercialization. Stuttgart: ibidem-Verlag.

Sahm, A. (2009). Civil society and mass media in Belarus. In S. Fischer (Ed.), Back from the cold? The EU and Belarus in 2009 (pp. 49-63). Paris: European Union Institute for Security Studies.

Schiller, H. I. (1976). Communication and cultural domination. New York: International Arts and Sciences Press.

Schmitt-Beck, R., \& Voltmer, K. (2007). The mass media in third-wave democracies: Gravediggers or seedsmen of democratic consolidation? In R. Gunther, J. R. Montero, \& H.-J. Puhle (Eds.), Democracy, intermediation, and voting on four continents. New York: Oxford University Press. 
Servaes, J. (2008). Introduction. In J. Servaes (Ed.), Communication for development and social change (Vol. 13, pp. 14-30). London: SAGE.

Sparks, C. (2007). Globalization, development and the mass media. London: SAGE PUBLICATIONS.

Stier, S. (2015). Democracy, autocracy and the news: The impact of regime type on media freedom. Democratization, 22(7), 1273-1295.

Szostek, J. (2014). Russia and the news media in Ukraine: A case of "soft power"? East European Politics and Societies and Cultures, 28(3), 463-486.

Štětka, V. (2012). From multinationals to business tycoons: Media ownership and journalistic autonomy in Central and Eastern Europe. International Journal of Press/Politics, 17(4), 433-456.

Tsetsura, K., Grynko, A., \& Klyueva, A. (2011). The media map project. Ukraine. Case study on donor support to independent media, 1990-2010. Internews.

Voltmer, K. (2013). The Media in transitional democracies. Cambridge: Polity Press.

Warren, T. C. (2014). Not by the sword alone: Soft power, mass media, and the production of state sovereignty. International Organization, 68(1), 111-141.

Welzel, C. (2009). Theories of democratization. In C. W. Haerpfer, P. Bernhagen, R. F. Inglehart, \& C. Welzel (Eds.), Democratization (pp. 74-91). Oxford and New York: Oxford University Press.

Zalas-Kamińska, K. (2019). Poles in Aid. Kraków: Księgarnia Akademicka.

Zielonka, J. (2015). Introduction: Fragile democracy, volatile politics, and the quest for a free media. In J. Zielonka (Ed.), Media and politics in new democracies. Europe in a comparative perspective (pp. 1-21). Oxford: Oxford University Press. 